\title{
Analisis Perbandingan Relationship Orientation Antara Mitra dengan Pengusaha Art Shop Pada Sentra-Sentra Kerajinan Tenun di Kabupaten Lombok Tengah
}

\author{
Lale Puspita Kembang \\ STMIK Mataram \\ Email : lale.kembangpuspita@gmail.com
}

\begin{abstract}
Abstrak - Bisnis kain tenun umumnya dilakukan di art shop, dimana pihak art shop sebagai penjual yang dibantu oleh beberapa elemen yang salah satunya melibatkan mitra untuk menunjang kesuksesan penjualan (bisnis). Akan tetapi yang terjadi adalah bisnis kain tenun di Lombok Tengah sedang mengalami penurunan penjualan kain tenun, di mana ada beberapa art shop yang tutup dan masih ada beberapa juga yang tetap bertahan. Walaupun dalam kondisi demikian, banyak diantara mitra menerima fee $40 \%-60 \%$ dari total belanja tamu yang dibawa. Ini tentu memberatkan untuk pengusaha art shop karena mereka juga harus mendapat keuntungan yang memadai untuk bisa mengembangkan usaha art shopnya dan mensejahterakan karyawan dan pengrajin tenun songket yang menjadi pemasoknya. Penelitian ini bertujuan untuk mengetahui tingkat dan perbedaan relationship orientation pengusaha art shop dengan mitra di Kabupaten Lombok Tengah. Manfaat penelitian dapat digunakan sebagai acuan dalam mengelola bisnis kerajinan songket sehingga bisa mempertahankan loyalitas pelanggan melalui strategi yang tepat ditengah ketatnya persaingan bisnis dan pasar pada saat ini. Jenis penelitian ini adalah penelitian kuantitatif deskriptif yaitu penelitian yang dilakukan dengan menjelaskan atau menggambarkan secara sistematis dengan fakta yang akurat sifat-sifat serta hubungan antar variable. Pengumpulan data dilakukan dengan menggunakan teknik wawancara dan pemberian kuesioner kepada responden sebagai sampel terpilih. Hasil Penelitian menunjukkan bahwa tingkat Relationship Orientation Pengusaha Art Shop termasuk dalam kategori tinggi sedangkan tingkat Relationship Orientation Mitra masuk kedalam kategori sangat tinggi. Ini artinya tingkat Relationship Orientation Mitra lebih tinggi dari pengusaha art shop, selanjutnya terdapat perbedaan yang signifikan antara relationship orientation yang terdiri dari Trust, Bonding, Communication, Shared Value, Empathy dan Reciprocity antara mitra dengan pengusaha art shop di sentra-sentra kerajinan tenun Lombok Tengah.
\end{abstract}

Kata kunci: Kain Songket, Art Shop, Relationship Orientation, Sentra Kerajinan Tenun

\section{Latar Belakang}

Bisnis kain tenun umumnya dilakukan di art shop, di mana pihak art shop sebagai penjual yang dibantu oleh beberapa elemen yang salah satunya melibatkan mitra untuk menunjang kesuksesan penjualan (bisnis). Akan tetapi yang terjadi adalah bisnis kain tenun di Lombok Tengah sedang mengalami penurunan jumlah art shop dan penurunan jumlah penjualan kain tenun, di mana ada beberapa art shop yang tutup dan masih ada beberapa juga yang tetap bertahan. Walaupun dalam kondisi demikian, banyak diantara mitra menerima fee $40 \%-60 \%$ dari total belanja tamu yang dibawa. Ini tentu memberatkan untuk pengusaha art shop karena mereka juga harus mendapat keuntungan yang memadai untuk bisa mengembangkan usaha art shopnya dan mensejahterakan karyawan dan pengrajin tenun songket yang menjadi pemasoknya. Belum lagi ada beberapa art shop yang membuat kesepakatan dengan para guide dan sopir yang datang membawa tamu dengan memanjakan mereka dengan memberikan biaya parkir sebesar 20-25 ribu pada guide dan sopir tersebut, tentu ini menjadi sebuah tekanan bagi para pengusaha art shop apalagi di tengah kondisi belum stabilnya ekonomi pariwisata di Lombok Tengah khususnya dalam bisnis kerajinan tenun yang memang akhirakhir ini cenderung mengalami penurunan pembeli bila dibandingkan dengan kondisi beberapa tahun lalu di mana tenun atau songket sangat dicari dan diminati sekali oleh para wisatawan lokal maupun mancanegara. Mereka tidak bisa berbuat banyak karena mereka juga sangat bergantung pada para guide, sopir dan travel agent tersebut karena pada umumnya tamu hanya mengunjungi atau ikut saja kemana guide atau travel agent membawa mereka untuk berbelanja oleh-oleh atau souvenir. Berbeda dengan kondisi sekitar sepuluh tahun yang lalu dimana bisnis songket sangat ramai pembeli dan 
pesanan oleh pelanggan lokal maupun mancanegara, bahkan banyak ibu-ibu rumah tangga yang menjadi pengrajin tenun bisa mencukupi kebutuhan rumah tangga dan kebutuhan lainnya hanya dari keuntungan menenun songket. Akan tetapi fakta yang peneliti temukan di lapangan sekarang sangat kontras dengan kondisi beberapa tahun lalu saat bisnis songket meraup keuntungan dengan prospek bisnis yang sangat menjanjikan di Lombok Tengah.

Adapun art shop yang dijadikan lokasi penelitian oleh peneliti adalah sentra-sentra kerajinan tenun yang ada di desa Sukarara dan desa Puyung, sedangkan desa Sade tidak dimasukkan sebagai lokasi penelitian. Walaupun Sade adalah desa wisata yang menawarkan pemandangan rumah adat khas Lombok dan tempat penjualan kain tenun akan tetapi kain tenun yang dijual disana lebih banyak yang buatan mesin bahkan kain tenun yang dijual disana pun banyak kain tenun yang di impor dari Thailand.

Penelitian ini bertujuan untuk mengetahui tingkat dan perbedaan relationship orientation pengusaha art shop dengan mitra di Kabupaten Lombok Tengah.

\section{Kajian Pustaka}

Beberapa hasil penelitian-penelitian terdahulu yang pernah dilakukan dan ada hubungannya dengan penelitian yang dilakukan, yakni: Analisis Efektifitas Hubungan Pemasaran Dan Faktor-Faktor Yang Mempengaruhinya (Studi Kasus pada AQUA di Jawa Tengah dan Jogjakarta) oleh Mudiantono dan Atmaja (2004). Tujuan penelitian ini untuk mengetahui bagaimana faktor-faktor seperti kepercayaan, komunikasi, komitmen dan kerjasama berpengaruh didalam upaya perusahaan meningkatkan efektivitas hubungan pemasaran dengan para retailernya. Populasi data penelitian ini adalah para retailer PT.Tirta Investama di wilayah Jateng dan DIY yang menurut database komputer Semester II tahun 2003 di Jateng -DIY terdapat retailer berjumlah 4220 orang. Untuk penelitian diambil sampel sebanyak 100 orang responden. Teknik analisis menggunakan Structural Equation Model (SEM). Hasil penelitian membuktikan bahwa efektifitas hubungan pemasaran dapat dibangun melalui dua cara, yaitu mengembangkan kepercayaan dan kerjasama dengan baik. Faktor terbesar yang mempengaruhi efektifitas hubungan pemasaran adalah kerjasama. Sebuah kerjasama yang terjalin dengan baik dapat dilihat dari baiknya koordinasi yang terjalin diantara kedua belah pihak. Koordinasi yang baik dapat menyebabkan terjadinya efektifitas hubungan pemasaran [1].

Proses Pengembangan Komitmen Hubungan Pemasaran Jangka Panjang oleh Indarjo (2002), Tujuan penelitian menemukan dan menganalisa faktor-faktor yang berperan dalam proses pengembangan komitmen untuk melakukan hubungan pemasaran jangka panjang. Populasi dalam penelitian ini adalah keseluruhan outlet PT. Sari Ayu di kota Semarang yang berjumlah 375. Sampel dilakukan dengan sistem kuota, dengan keseluruhan sampel sebesar 100. Teknik analisa menggunakan SEM. Hasil penelitian disimpulkan bahwa, proses yang mengarah pada pengembangan komitmen untuk melakukan kerjasama jangka panjang dimulai dengan adanya komunikasi, reputasi, dan kepuasan yang mempengaruhi tinggi rendahnya kepercayaan. Bersama-sama dengan Saling Ketergantungan, kepercayaan mempengaruhi terjadinya komitmen untuk melakukan hubungan kerjasama pemasaran jangka panjang [2].

Analisa Kualitas Layanan Sebagai Pengukur Loyalitas Pelanggan Hotel Majapahit Surabaya Dengan Pemasaran Relasional Sebagai Variabel Intervening oleh Japarianto (2007). Tujuan penelitian meneliti pengaruh kualitas layanan terhadap kesetiaan pelanggan Hotel Majapahit dengan menggunakan variabel pemasaran relasional sebagai variabel intervening. Populasi dalam penelitian ini adalah pelanggan Hotel Majapahit Surabaya yang dalam jangka waktu 1 tahun terakhir melakukan kunjungan sebanyak 1-5 kali dan menggunakan fasilitas pelayanan kamar (menginap di hotel) dengan jumlah sampel sebanyak 272 orang. Teknik analisa data dalam penelitian ini menggunakan statistik deskriptif, Analisa faktor dan Analisa regresi. Hasil penelitian menunjukkan bahwa program pemasaran relasional yang dijalankan oleh pihak hotel tidak mempunyai kontribusi nyata dalam meningkatkan loyalitas pelanggan Hotel Majapahit Surabaya [3].

Pengaruh Pemasaran Relasional Terhadap Keinginan Pasien Rawat Inap Membangun Hubungan Jangka Panjang di Rumah Sakit Islam Faisal Makassar oleh Haerani. Tujuan Penelitian untuk menganalisis pengaruh pemasaran relasional terhadap keinginan pasien rawat inap membangun hubungan jangka panjang di RS Islam Faisal Makassar. Teknik analisis data menggunakan uji chi-square dan regresi logistik. Populasi penelitian sebanyak 5091 pasien rawat 
inap, dengan jumlah sampel sebanyak 100 pasien. Hasil penelitian menunjukkan bahwa sebagian besar responden berada pada kelompok umur $>40-50$ tahun (32\%), berjenis kelamin perempuan (59\%), berpendidikan S1 (57\%), dan bekerja sebagai PNS (31\%). Hasil analisis menunjukkan bahwa ada pengaruh antara kepercayaan $(p=0.014)$, empati $(p=0.004)$, komunikasi $(p=0.000)$, hubungan timbal balik $(p=0.023)$, dan respek $(p=0.003)$ dengan keinginan pasien membangun hubungan jangka panjang. Hasil analisis pengaruh bersama-sama, yakni komunikasi $(p=0.000)$ dan respek $(p=0.011)$ berpengaruh terhadap keinginan pasien membangun hubungan jangka panjang [4].

Pemasaran Relasional dan Kualitas Layanan Pengaruhnya Terhadap Loyalitas Pelanggan di Matahari Departement Store Manado oleh Kipu (2013). Tujuan penelitian untuk mengetahui apakah pemasaran relasional dan kualitas layanan, berpengaruh terhadap loyalitas pelanggan. Alat analisis yang digunakan regresi linear berganda. Sampel pada penelitian ini sebanyak 100 orang yang diambil dari seluruh pelanggan Matahari Departement Store. Hasil penelitian menunjukan bahwa secara bersama pemasaran relasional dan kualitas layanan, berpengaruh terhadap loyalitas pelanggan [5].

Adapun persamaan penelitian-penelitian terdahulu dengan penelitian ini adalah samasama meneliti mengenai Relationship Orientation berikut beberapa variabel /komponen yang terdapat didalamnya seperti Trust, Communication, Bonding, Shared Value, Empathy, dan Reciprocity. Sedangkan Perbedaannya, selain berbeda pada objek penelitiannya juga terdapat perbedaan didalam teknik pengambilan sampel dan alat analisis yang digunakan.

\section{Metode}

\subsection{Jenis Penelitian}

Jenis penelitian yang digunakan dalam penelitian ini adalah penelitian kuantitatif deskriptif yaitu: penelitian yang dilakukan dengan menjelaskan atau menggambarkan secara sistematis dengan fakta yang akurat sifat-sifat serta hubungan antar variable [6].

\subsection{Teknik dan Alat Pengumpulan Data}

Pengumpulan data dilakukan dengan menggunakan teknik wawancara dan pemberian kuesioner kepada responden sebagai sampel terpilih. Pengisian kuesioner oleh responden dilakukan melalui self administered questionaire, dimana jenis pertanyaan yang digunakan dalam kueisioner penelitian merupakan pertanyaan terstruktur. Jawaban pertanyaan terstruktur dibuat berdasarkan skala likert untuk mengetahui tanggapan responden terhadap suatu kuesioner apakah ada perbedaan relationship orientation atau tidak dari kedua hubungan mitra tersebut.

\subsection{Identifikasi dan Pengukuran Variabel}

Indikator variable terdiri dari Trust, Bonding, Communication, Shared Value, Empathy, dan Reciprocity.

Pengukuran variabel dalam penelitian ini menggunakan skala Likert 7 point di mana masing-masing pertanyaan diberi skor 1 sampai 7, sedangkan bobot masing-masing jawaban adalah sangat setuju sekali dengan bobot 7 , sangat setuju dengan bobot 6 , setuju dengan bobot 5 , netral dengan bobot 4 , tidak setuju dengan bobot 3 , sangat tidak setuju dengan bobot 2 dan sangat tidak setuju sekali dengan bobot 1 [7].

Tabel 3.1 Interval Kelas

\begin{tabular}{rcc}
\hline No & Interval & Keterangan \\
\hline $\mathbf{1}$ & $1-1,85$ & STSS/STTS \\
\hline $\mathbf{2}$ & $1,86-2,71$ & STS/STT \\
\hline $\mathbf{3}$ & $2,72-3,57$ & TS/TT \\
\hline $\mathbf{4}$ & $3,58-4,43$ & $\mathrm{~N} / \mathrm{N}$ \\
\hline $\mathbf{5}$ & $4,44-5,29$ & $\mathrm{~S} / \mathrm{T}$ \\
\hline $\mathbf{6}$ & $5,30-6,15$ & $\mathrm{SS} / \mathrm{ST}$ \\
\hline $\mathbf{7}$ & $6,16-\mathbf{7}$ & SSS/STS
\end{tabular}

Keterangan:

STTS = Sangat Tidak Tinggi Sekali

STT = Sangat Tidak Tinggi

TT = Tidak tinggi

$\mathrm{N} \quad=$ Netral (cukup)

$\mathrm{T}=$ Tinggi

ST = Sangat

STS $=$ Sangat Tinggi Sekali.

\subsection{Model Analisis Data}

Metode analisis yang digunakan dalam penelitian ini adalah Analisis Deskriptif Persentase. Metode ini digunakan untuk mengkaji variabel yang ada pada penelitian yang terdiri dari variabel Relationship Orientation Mitra dan Relationship Orientation Pengusaha art shop. Deskriptif persentase ini diolah dengan cara frekuensi dibagi dengan jumlah responden dikali 100 persen, seperti berikut ini:

$$
P=\stackrel{f}{-----} \times 100 \%
$$


$\mathrm{N}$

Keterangan :

$\begin{array}{ll}\mathrm{P} & : \text { Persentase } \\ \mathrm{f} & : \text { Frekuensi } \\ \mathrm{N} & : \text { Jumlah responden } \\ 100 \% & : \text { Bilangan tetap }\end{array}$

\subsection{Uji Beda T-Test}

Untuk pembuktian hipotesis komparatif dilakukan menggunakan uji beda T-Test atau TScore. Alasan peneliti menggunakan T-Test dalam menganalisa data adalah karena T-Test pada prinsipnya merupakan suatu teknik statistik untuk menguji hipotesis tentang ada tidaknya perbedaan yang signifikan antara dua kelompok sampel dengan jalan perbedaan rata-rata (mean). Dalam penelitian komparatif ini, penulis menggunakan uji beda T-Test atau Uji hipotesis beda dua mean untuk observasi tidak berpasangan (antara Mitra dengan Pengusaha Art shop).

\section{Hasil dan Pembahasan}

\subsection{Analisis Perbandingan Frekuensi}

Secara garis besar perbandingan relationship orientation antara pengusaha art shop dengan mitra di sentra-sentra kerajinan tenun Lombok Tengah dengan menggunakan nilai ratarata jumlah frekuensi dari masing-komponen Relationship Orientation dapat dilihat pada tabel 4.1 di bawah ini.

Tabel 4.1 Perhitungan nilai rata-rata Relationship Orientation pengusaha art shop dan mitra

\begin{tabular}{lcc}
\hline \multicolumn{1}{c}{ Keterangan } & $\begin{array}{c}\text { Pengusaha } \\
\text { Artshop }\end{array}$ & Mitra \\
\hline Trust & 5.06 & 5.89 \\
\hline Bonding & 5.63 & 5.99 \\
\hline Communication & 5.28 & 5.00 \\
\hline Shared Value & 4.90 & 5.04 \\
\hline Empathy & 5.00 & 5.12 \\
\hline Reciprocity & 5.41 & 5.05 \\
\hline Jumlah nilai rata-rata & 5.27 & 5.34 \\
& & \\
\hline
\end{tabular}

Dari perhitungan nilai rata-rata frekuensi relationship orientation Pengusaha Art shop dan Mitra, bahwa relationship orientation Mitra lebih tinggi daripada relationship orientation Pengusaha art shop. Dimana nilai rata-rata mitra sebanyak 5.34 masuk dalam kategori sangat tinggi (ST), sedangkan nilai rata-rata relationship orientation pengusaha art shop masuk sebanyak 5.27. sehingga jawaban responden pengusaha art shop masuk kedalam kategori tinggi $(\mathrm{T})$.

\subsection{Uji Beda T - Test}

Pengujian hipotesis untuk analisis perbandingan relationship orientation antara mitra dengan pengusaha art shop di sentra-sentra kerajinan tenun Lombok Tengah dapat dilihat pada tabel 4.2 berikut ini:

Tabel 4.2 Nilai rata-rata Mean dan probabilitas pengusaha art shop dan mitra mengenai Relationship Orientation komponen Trust

\begin{tabular}{|c|c|c|c|c|}
\hline \multicolumn{3}{|c|}{ R O Pengusaha Art Shop } & \multicolumn{2}{|c|}{ R O Mitra } \\
\hline Item & Mean & Item & Mean & Sig-t \\
\hline $\begin{array}{l}\text { Relationship } \\
\text { Orientation } \\
\text { Trust. } 1\end{array}$ & 5.82 & $\begin{array}{l}\text { Relationship } \\
\text { Orientation } \\
\text { Trust. } 1\end{array}$ & 6.01 & 0.00 \\
\hline $\begin{array}{l}\text { Relationship } \\
\text { Orientation } \\
\text { Trust. } 2\end{array}$ & 4.64 & $\begin{array}{l}\text { Relationship } \\
\text { Orientation } \\
\text { Trust. } 2\end{array}$ & 5.65 & 0.00 \\
\hline $\begin{array}{l}\text { Relationship } \\
\text { Orientation } \\
\text { Trust. } 3\end{array}$ & 4.70 & $\begin{array}{l}\text { Relationship } \\
\text { Orientation } \\
\text { Trust. } 3\end{array}$ & 5.20 & 0.00 \\
\hline $\begin{array}{l}\text { Relationship } \\
\text { Orientation } \\
\text { Trust. } 4\end{array}$ & 5.11 & $\begin{array}{l}\text { Relationship } \\
\text { Orientation } \\
\text { Trust. } 4\end{array}$ & 5.68 & 0.00 \\
\hline
\end{tabular}

Dari Tabel 4.2 di atas, dengan perhitungan uji Beda T-Test, ditemukan relative ada perbedaan antara relationship orientation pengusaha art shop dengan mitra dari tanggapan responden masingmasing item terhadap komponen Trust secara signifikan. Hal ini ditunjukkan oleh nilai probabilitas (sig-t) 0.00 berada dibawah level of significance yang digunakan $(\alpha=0,05)$.

Tabel 4.3 Nilai rata-rata Mean dan probabilitas pengusaha art shop dan mitra mengenai relationship orientation komponen Bonding

\begin{tabular}{lllll}
\hline \multicolumn{2}{c}{$R$ O Pengusaha Art Shop } & \multicolumn{2}{c}{$R$ O Mitra } \\
\hline \multicolumn{1}{c}{ Item } & Mean & \multicolumn{1}{c}{ Item } & Mean & Sig-t \\
\hline $\begin{array}{l}\text { Relationship } \\
\text { Orientation }\end{array}$ & 5.82 & $\begin{array}{l}\text { Relationship } \\
\text { Orientation } \\
\text { Bonding.1 }\end{array}$ & 5.56 & 0.00 \\
Bonding.1 & & \\
\hline $\begin{array}{l}\text { Relationship } \\
\text { Orientation }\end{array}$ & 5.64 & $\begin{array}{l}\text { Relationship } \\
\text { Orientation } \\
\text { Bonding.2 }\end{array}$ & 6.11 & 0.00 \\
\hline $\begin{array}{l}\text { Relationship } \\
\text { Orientation }\end{array}$ & 5.52 & $\begin{array}{l}\text { Relationship } \\
\text { Brientation } \\
\text { Bonding.3 }\end{array}$ & 6.11 & 0.00 \\
\hline
\end{tabular}

Dari Tabel 4.3 di atas, dengan perhitungan uji Beda T-Test, ditemukan relative ada perbedaan antara relationship orientation pengusaha art shop 
dengan mitra dari tanggapan responden masingmasing item terhadap komponen Bonding secara signifikan. Hal ini ditunjukkan oleh nilai probabilitas (sig-t) 0.00 berada dibawah level of significance yang digunakan $(\alpha=0,05)$.

Tabel 4.4 Nilai rata-rata Mean dan probabilitas pengusaha art shop dan mitra mengenai relationship orientation komponen Communication

\begin{tabular}{|c|c|c|c|c|}
\hline \multicolumn{2}{|c|}{ RO Penqusaha Art Shop } & \multicolumn{3}{|c|}{ RO Mitra } \\
\hline Item & Mean & Item & Mean & Sig-t \\
\hline $\begin{array}{l}\text { Relationship } \\
\text { Orientation } \\
\text { Communication. } \\
1\end{array}$ & 5.58 & $\begin{array}{l}\text { Relationship } \\
\text { Orientation } \\
\text { Communication. } \\
1\end{array}$ & 4.61 & 0.00 \\
\hline $\begin{array}{l}\text { Relationship } \\
\text { Orientation } \\
\text { Communication. } \\
2\end{array}$ & 4.94 & $\begin{array}{l}\text { Relationship } \\
\text { Orientation } \\
\text { Communication. } \\
2\end{array}$ & 4.81 & 0.00 \\
\hline $\begin{array}{l}\text { Relationship } \\
\text { Orientation } \\
\text { Communication. } \\
3\end{array}$ & 5.41 & $\begin{array}{l}\text { Relationship } \\
\text { Orientation } \\
\text { Communication. } \\
3\end{array}$ & 5.13 & 0.00 \\
\hline $\begin{array}{l}\text { Relationship } \\
\text { Orientation } \\
\text { Communication. } \\
4\end{array}$ & 5.29 & $\begin{array}{l}\text { Relationship } \\
\text { Orientation } \\
\text { Communication. } \\
4\end{array}$ & 5.10 & 0.00 \\
\hline
\end{tabular}

Dari Tabel 4.4 di atas, dengan perhitungan uji Beda T-Test, ditemukan relative ada perbedaan antara relationship orientation pengusaha art shop dengan mitra dari tanggapan responden masing-masing item terhadap komponen Communication secara signifikan. Hal ini ditunjukkan oleh nilai probabilitas (sig-t) 0.00 berada dibawah level of significance yang digunakan $(\alpha=0,05)$

Tabel 4.5 Nilai rata-rata Mean dan probabilitas pengusaha art shop dan mitra mengenai relationship orientation komponen shared value

\begin{tabular}{lclcc}
\hline \multicolumn{2}{c}{ RO Pengusaha Art Shop } & \multicolumn{3}{c}{$R$ M Mitra } \\
\hline \multicolumn{1}{c}{ Item } & Mean & \multicolumn{1}{c}{ Item } & Mean & Sig-t \\
\hline $\begin{array}{l}\text { Relationship } \\
\text { Orientation Shared } \\
\text { Value. 1 }\end{array}$ & 4.64 & $\begin{array}{l}\text { Relationship } \\
\text { Orientation } \\
\text { Shared } \\
\text { Value. 1 }\end{array}$ & 5.58 & 0.00 \\
\hline $\begin{array}{l}\text { Relationship } \\
\text { Orientation Shared } \\
\text { Value. 2 }\end{array}$ & 4.52 & $\begin{array}{l}\text { Relationship } \\
\text { Orientation } \\
\text { Shared }\end{array}$ & 4.83 & 0.00 \\
$\begin{array}{l}\text { Value. 2 } \\
\text { Relationship }\end{array}$ & 5.47 & $\begin{array}{l}\text { Relationship } \\
\text { Orientation } \\
\text { Value. 3 }\end{array}$ & 5.16 & 0.00 \\
\hline $\begin{array}{l}\text { Shared } \\
\text { Value. 3 }\end{array}$ & & \\
\hline $\begin{array}{l}\text { Relationship } \\
\text { Orientation Shared } \\
\text { Value. 4 }\end{array}$ & 5.00 & $\begin{array}{l}\text { Relationship } \\
\text { Orientation } \\
\text { Shared } \\
\text { Value. 4 }\end{array}$ & & \\
\hline
\end{tabular}

Dari Tabel 4.5 di atas, dengan perhitungan uji Beda $\mathrm{T}$-Test, ditemukan relative ada perbedaan antara relationship orientation pengusaha art shop dengan mitra dari tanggapan responden masing-masing item terhadap komponen Shared Value secara signifikan. Hal ini ditunjukkan oleh nilai probabilitas (sig-t) 0.00 berada dibawah level of significance yang digunakan $(\alpha=0,05)$.

Tabel 4.6 Nilai rata-rata Mean dan probabilitas pengusaha art shop dan mitra mengenai relationship orientation komponen Empathy

\begin{tabular}{lclcc}
\hline $\begin{array}{c}R \text { O Pengusaha Art Shop } \\
\text { Mitra }\end{array}$ & Mean & \multicolumn{1}{c}{ Item } & Mean & Sig-t \\
\hline \multicolumn{1}{c}{ Item } & Relationship & 5.20 & 0.00 \\
\hline $\begin{array}{l}\text { Relationship } \\
\text { Orientation } \\
\text { Empathy. 1 }\end{array}$ & 5.05 & $\begin{array}{l}\text { Relationtation } \\
\text { Orient } \\
\text { Empathy. 1 }\end{array}$ & & \\
\hline $\begin{array}{l}\text { Relationship } \\
\text { Orientation } \\
\text { Empathy. 2 }\end{array}$ & 5.58 & $\begin{array}{l}\text { Relationship } \\
\text { Orientation } \\
\text { Empathy. 2 }\end{array}$ & 5.10 & 0.00 \\
\hline $\begin{array}{l}\text { Relationship } \\
\text { Orientation } \\
\text { Empathy. 3 }\end{array}$ & 4.64 & $\begin{array}{l}\text { Relationship } \\
\text { Orientation } \\
\text { Empathy. 3 }\end{array}$ & 5.20 & 0.00 \\
\hline $\begin{array}{l}\text { Relationship } \\
\text { Orientation } \\
\text { Empathy. 4 }\end{array}$ & 5.52 & $\begin{array}{l}\text { Relationship } \\
\text { Orientation } \\
\text { Empathy. 4 }\end{array}$ & 5.05 & 0.00 \\
\hline
\end{tabular}

Dari Tabel 4.6 diatas, dengan perhitungan uji Beda T-Test, ditemukan relative ada perbedaan antara relationship orientation pengusaha art shop dengan mitra dari tanggapan responden masing-masing item terhadap komponen Empathy secara signifikan. Hal ini ditunjukkan oleh nilai probabilitas (sig-t) 0.00 berada dibawah level of significance yang digunakan $(\alpha=0,05)$.

Tabel 4.7 Nilai rata-rata Mean dan probabilitas pengusaha art shop dan mitra mengenai relationship orientation komponen reciprocity

\begin{tabular}{|c|c|c|c|c|}
\hline \multicolumn{3}{|c|}{ RO Pengusaha Art Shop } & \multicolumn{2}{|c|}{$R O$ Mitra } \\
\hline Item & Mean & Item & Mean & Sig-t \\
\hline $\begin{array}{l}\text { Relationship } \\
\text { Orientation } \\
\text { Reciprocity. } 1\end{array}$ & 5.35 & $\begin{array}{l}\text { Relationship } \\
\text { Orientation } \\
\text { Reciprocity. } 1\end{array}$ & 4.71 & 0.00 \\
\hline $\begin{array}{l}\text { Relationship } \\
\text { Orientation } \\
\text { Reciprocity. } 2\end{array}$ & 5.47 & $\begin{array}{l}\text { Relationship } \\
\text { Orientation } \\
\text { Reciprocity. } 2\end{array}$ & 5.43 & 0.00 \\
\hline
\end{tabular}

Dari Tabel 4.7 di atas, dengan perhitungan uji Beda T-Test, ditemukan relative ada perbedaan antara relationship orientation pengusaha art shop dengan mitra dari tanggapan responden masing-masing item terhadap relationship orientation komponen Reciprocity secara signifikan. Hal ini ditunjukkan oleh nilai 
probabilitas (sig-t) 0.00 berada dibawah level of significance yang digunakan $(\alpha=0,05)$.

Tabel 4.8 Deskripsi perbedaan Komponen penelitian Analisis Perbandingan Relationship Orientation antara Mitra dengan Pengusaha Art Shop di Sentra-Sentra Kerajinan Tenun Lombok Tengah

\begin{tabular}{lclcc}
\hline$R$ O Pengusaha Art Shop & \multicolumn{1}{c}{$R$ Mitra } \\
\hline \multicolumn{1}{c}{ Item } & Mean & \multicolumn{1}{c}{ Item } & Mean & Sig-t \\
\hline $\begin{array}{l}\text { Relationship } \\
\text { Orientation Trust }\end{array}$ & 20.27 & $\begin{array}{l}\text { Relationship } \\
\text { Orientation } \\
\text { Trust }\end{array}$ & 22.54 & 0.00 \\
\hline $\begin{array}{l}\text { Relationship } \\
\text { Orientation }\end{array}$ & 16.98 & $\begin{array}{l}\text { Relationship } \\
\text { Orientation } \\
\text { Bonding }\end{array}$ & 17.78 & 0.00 \\
\hline $\begin{array}{l}\text { Relationship } \\
\text { Orientation } \\
\text { Communication }\end{array}$ & 21.22 & $\begin{array}{l}\text { Relationship } \\
\text { Orientation } \\
\text { Communicat } \\
\text { ion }\end{array}$ & 19.65 & 0.00 \\
\hline $\begin{array}{l}\text { Relationship } \\
\text { Orientation } \\
\text { Shared Value }\end{array}$ & 19.63 & $\begin{array}{l}\text { Relationship } \\
\text { Orientation } \\
\text { Shared } \\
\text { Value }\end{array}$ & 21.00 & 0.00 \\
\hline $\begin{array}{l}\text { Relationship } \\
\text { Orientation } \\
\text { Empathy }\end{array}$ & 20.79 & $\begin{array}{l}\text { Relationship } \\
\text { Orientation } \\
\text { Empathy }\end{array}$ & 20.55 & 0.00 \\
\hline $\begin{array}{l}\text { Relationship } \\
\text { Orientation } \\
\text { Reciprocity }\end{array}$ & 10.82 & $\begin{array}{l}\text { Relationship } \\
\text { Orientation } \\
\text { Reciprocity }\end{array}$ & 10.14 & 0.00 \\
\hline
\end{tabular}

Dari perhitungan uji Beda T-Test, ditemukan perbedaan relationship orientation antara Pengusaha art shop dengan Mitra secara signifikan. Dimana Relationship Orientation Mitra lebih tinggi dengan jumlah rata-rata Mean sebanyak 111.66, sedangkan jumlah rata-rata Mean Relationship Orientation Pengusaha Art shop sebanyak 109.71. Hal ini juga ditunjukkan nilai probabilitas (sig-t) 0.00 berada dibawah level of significance yang digunakan ( $\alpha=00,05)$, sehingga hipotesis yang menyatakan ada perbedaan Relationship Orientation antara mitra dengan pengusaha art shop diterima.

\subsection{Interpretasi Hasil}

Berdasarkan hasil pengujian hipotesis dengan Uji - t diketahui bahwa ada perbedaan antara Relationship Orientation Pengusaha Art shop dengan Mitra di sentra-sentra Kerajinan Tenun Lombok Tengah. Hal tersebut dapat diketahui dari penjelasan tiap -tiap komponen berikut ini.

Analisis perbandingan Relationship Orientation Pengusaha art shop dan Mitra terhadap komponen Trust diketahui memiliki perbedaan yang signifikan. Dalam penelitian ini yang lebih tinggi adalah Relationship Orientation
Trust Mitra. Hal ini dapat diketahui dari Mean Relationship Orientation Trust Mitra yang lebih besar Pengusaha art shop yakni sebesar 22.54 $>20.27$. Perbedaan ini bisa disebabkan karena Pengusaha art shop selalu menjaga kejujuran dan kepercayaan dengan para mitranya, sehingga rasa kepercayaan Mitra terhadap pengusaha art shop sangat tinggi.

\section{Analisis perbandingan Relationship} Orientation antara Pengusaha art shop dan Mitra terhadap komponen Bonding diketahui memiliki perbedaan yang signifikan. Dalam penelitian ini yang lebih tinggi adalah Relationship Orientation Bonding Mitra. Hal ini dapat diketahui dari Mean Relationship Orientation Bonding Mitra yang lebih besar dari Pengusaha art shop yakni sebesar 17.78 $>16.98$. Perbedaan ini bisa terjadi karena dalam mendapatkan keuntungan atau penghasilan dari profesinya Para mitra sangat mengandalkan fee dari para pengusaha art shop. Sehingga tingkat ketergantungan para mitra terhadap para pengusaha art shop tinggi.

\section{Analisis perbandingan Relationship} Orientation antara Pengusaha art shop dan Mitra terhadap komponen Communication diketahui memiliki perbedaan yang signifikan. Dalam penelitian ini yang lebih tinggi adalah Relationship Orientation Communication Pengusaha art shop. Hal ini dapat diketahui dari Mean Relationship Orientation Communication Pengusaha art shop yang lebih besar dari Mitra yakni sebesar 21.22>19.65. Perbedaan ini bisa terjadi karena untuk bisa tetap mendapatkan pembeli atau pengunjung para pengusaha art shop secara intens selalu menjalin komunikasi dengan para mitra supaya mitra selalu membawa para tamu atau pembeli untuk datang berbelanja ke art shop mereka.

Analisis perbandingan Relationship Orientation antara Pengusaha art shop dan Mitra terhadap komponen Shared Value diketahui memiliki perbedaan yang signifikan. Dalam penelitian ini yang lebih tinggi adalah Relationship Orientation Shared Value Mitra. Hal ini dapat diketahui dari Mean Relationship Orientation Shared Value Mitra yang lebih besar dari Pengusaha art shop yakni sebesar 21.00>19.63. Perbedaan ini bisa terjadi karena para Mitra sangat memahami untuk bisa berinteraksi dengan tamu dan para pengusaha art shop mereka benar-benar harus tahu nilai -nilai bersama yang di anut, sehingga dengan begitu hubungan baik dengan para tamu dan para pengusaha art shop bisa terjalin dalam jangka panjang dan dalam hubungan yang 
menyenangkan namun tetap santun sesuai budaya masing-masing.

Analisis perbandingan Relationship Orientation antara Pengusaha art shop dan Mitra terhadap komponen Empathy diketahui memiliki perbedaan yang signifikan. Dalam penelitian ini yang lebih tinggi adalah Relationship Orientation Empathy Pengusaha art shop. Hal ini dapat diketahui dari Mean Relationship Orientation Empathy Pengusaha art shop yang lebih besar dari Mitra yakni sebesar 20.79>20.55. Perbedaan ini bisa terjadi karena para pengusaha art shop selalu berusaha merasakan apa yang dirasakan dan difikirkan oleh para mitra. Sehingga dengan begitu rasa kedekatan dan keakraban serta rasa kepedulian para pengusaha art shop terhadap mitra tinggi yang bisa menunjang hubungan baik dan jangka panjang bisa berlanjut diantara kedua pihak.

Analisis perbandingan Relationship Orientation antara Pengusaha art shop dan Mitra terhadap komponen Reciprocity diketahui memiliki perbedaan yang signifikan. Dalam penelitian ini yang lebih tinggi adalah Relationship Orientation Reciprocity Pengusaha art shop. Hal ini dapat diketahui dari Mean Relationship Orientation Reciprocity Pengusaha art shop yang lebih besar dari Mitra yakni sebesar 10.82>10.14. Perbedaan ini bisa terjadi karena para pengusaha art shop selalu merasa berhutang budi dan ingin membalas kebaikan Mitra disaat Mitra memberikan bantuannya terhadap pengusaha art shop. Sehingga dengan begitu para Mitra bisa merasa lebih nyaman dan merasa punya hubungan yang erat dengan pengusaha art shop.

\section{Penutup}

Berdasarkan Hasil Penelitian dan pembahasan dapat diambil kesimpulan bahwa

1. Tingkat Relationship Orientation Pengusaha Art Shop termasuk dalam ketgori tinggi sedangkan tingkat Relationship Orientation Mitra masuk kedalam kategori sangat tinggi. Ini artinya tingkat Relationship Orientation Mitra lebih tinggi dari pengusaha art shop.

2. Ada perbedaan yang signifikan antara relationship orientation yang terdiri dari Trust, Bonding, Communication, Shared Value, Empathy dan Reciprocity antara mitra dengan pengusaha art shop di sentra-sentra kerajinan tenun Lombok Tengah.

\section{Pustaka}

D. Ya. A. Mudiantono, "Analisis Efektifitas Hubungan Pemasaran Dan Faktor-Faktor
Yang Mempengaruhinya (Studi Kasus pada AQUA di Jawa Tengah dan Jogjakarta)," J. Bisnis dan Ekon., 2004.

M. Indarjo, "Proses Pengembangan Komitmen Hubungan Pemasaran Jangka Panjang," J. Sains Pemasar. Indones., vol. 1, no. 2, pp. 152-161, 2002.

E. Japarianto, “Analisa Kualitas Layanan Sebagai Pengukur Loyalitas Pelanggan Hotel Majapahit Surabaya Dengan Pemasaran Relasional Sebagai Variabel Intervening," J. Perhotelan Petra, vol. 3, no. 1, pp. 3442, 2007.

S. Ha. Muhammad Irham Umar, Darmawansyah, "Pengaruh Pemasaran Relasional Terhadap Keinginan Pasien Rawat Inap Membangun Hubungan Jangka Panjang di Rumah Sakit Islam Faisal Makassar," J. Kesehat. Masy. Unhas, 2013.

M. S. Kipu, "Pemasaran Relasional dan Kualitas Layanan Pengaruhnya Terhadap Loyalitas Pelanggan di Matahari Departement Store Manado," J. EMBA, vol. 1, no. 3, 2013.

Sugiyono, Metode Penelitian Bisnis. Bandung: CV. Alfabeta, 2003.

S. Azwar, Reliabilitas dan Validitas. Yogyakarta: Pustaka Pelajar. Offset, 2004. 